\title{
Medication profile and potential drug interactions in diabetes mellitus with hypertension outpatient at RSUD dr. H. Andi Abdurrahman Noor
}

\section{Profil pengobatan dan potensi interaksi obat pada pasien diabetes melitus komplikasi hipertensi di RSUD dr. H. Andi Abdurrahman Noor}

\author{
Sinta Rachmawati*, Fania Pratiwi, Ika Norcahyanti \\ Fakultas Fakultas Farmasi, Universitas Jember, Jember, Indonesia \\ *Corresponding author: sinta.rachmawati@unej.ac.id
}

\begin{abstract}
Background: Diabetes mellitus is a metabolic disease, characterized by hyperglycemia. It occurs due to impaired insulin secretion, insulin action, or both. Diabetes mellitus is a chronic disease that is often accompanied by complications, one of which is hypertension, so that drug interactions cannot be avoided.

Objective: This study aimed to determine the medication profile and potential drug interactions in diabetes mellitus outpatient with hypertension at RSUD dr. H. Andi Abdurrahman Noor.

Method: It was a descriptive study. The data was obtained from diabetes with hypertension outpatient in three months (October-December 2020). To analyze potential drug interaction, used drugs.com, Medscape and Stockley for literature.

Results: The medication profile showed that insulin aspart (43.84\%) and the combination of candesartan and amlodipine (52.05\%) were the most used drugs. The most common potential drug interactions were found between insulin and candesartan (73.34\%) with moderate severity.

Conclusion: Insulin aspart was the most used of antidiabetic. Candesartan plus amlodipine was the most widely used antihypertensive. Both types of drugs (insulin and candesartan) have the potential for drug interactions.
\end{abstract}

Keywords: antidiabetic, antihypertensive, drug interaction

\section{Intisari}

Latar belakang: Diabetes melitus merupakan penyakit metabolik yang ditandai dengan hiperglikemia yang disebabkan adanya gangguan sekresi insulin, kerja insulin, ataupun keduanya. Diabetes melitus merupakan penyakit kronis yang sering disertai komplikasi, salah satunya hipertensi, sehingga kejadian interaksi obat tidak dapat dielakkan.

Tujuan: Penelitian ini bertujuan untuk mengetahui profil pengobatan dan potensi interaksi obat pada pasien rawat jalan yang didiagnosis diabetes melitus komplikasi hipertensi di RSUD dr. H. Andi Abdurrahman Noor.

Metode: Penelitian ini bersifat deskriptif. Data diperoleh dari lembar resep pasien rawat jalan yang didiagnosis diabetes dengan komplikasi hipertensi selama 3 bulan (Oktober-Desember 2020). Analisis potensi interaksi obat menggunakan sumber drugs.com, Medscape dan Stockley sebagai rujukan.

Hasil: Profil pengobatan menunjukkan insulin aspart $(43,84 \%)$ serta kombinasi kandesartan dan amlodipin $(52,05 \%)$ merupakan obat-obatan yang paling banyak digunakan. Potensi interaksi obat yang paling banyak ditemukan terjadi antara insulin dengan kandesartan sebesar 73,34\% dengan tingkat keparahan sedang.

Kesimpulan: Insulin aspart adalah antidiabetes yang paling banyak digunakan, sedangkan kandesartan yang dikombinasi dengan amlodipin merupakan antihipertensi yang paling banyak digunakan. Kedua jenis obat tersebut (insulin dan kandesartan) memiliki potensi interaksi obat.

Kata kunci : antidiabetes, antihipertensi, interaksi obat 


\section{Pendahuluan}

Diabetes melitus (DM) atau yang biasanya dikenal dengan kencing manis adalah salah satu dari penyakit metabolik yang ditandai dengan tingginya kadar gula di dalam darah. Penyakit ini disebabkan adanya gangguan sekresi insulin, kerja insulin, ataupun keduanya. DM dapat dibagi menjadi empat kategori yaitu tipe 1, tipe 2, tipe spesifik lain serta DM gestasional. International Diabetes Foundation (IDF) pada tahun 2019 menyatakan Indonesia menempati 10 besar negara yang memiliki populasi penderita diabetes melitus tertinggi di dunia, yakni peringkat ke 7 dengan kisaran angka 10,7 juta jiwa (IDF, 2019). Riset Kesehatan Dasar (Riskesdas) 2018 menggambarkan peningkatan yang signifikan pada prevalensi penderita diabetes melitus di Indonesia, dari 6,9\% pada tahun 2013 menjadi 8,5\% pada tahun 2018 (Kemenkes, 2018). Data Dinas Kesehatan Provinsi Kalimantan Selatan juga menunjukkan bahwa pada tahun 2019 terdapat peningkatan angka penderita diabetes melitus sebanyak $71 \%$ atau setara dengan 736 orang di Kabupaten Tanah Bumbu dimana pada tahun sebelumnya angka tersebut masih berada pada total 430 jiwa penderita (Dinkes Kalsel, 2020).

Penyakit DM merupakan suatu penyakit kronis yang sering diiringi dengan komplikasi dan membutuhkan perawatan medis yang berkelanjutan (ADA, 2020). Menurut American Association of Clinical Endocrinologists Medical Guidelines for Clinical Practice for the Management of Diabetes Mellitus, salah satu risiko yang serius dalam komplikasi diabetes melitus adalah hipertensi (Rodbard et al., 2007). Tingginya kadar gula di dalam darah akan menyebabkan penempelan gula di dinding pembuluh darah dan terjadilah proses oksidasi. Pada proses ini, gula akan berikatan dengan protein yang ada di dinding pembuluh darah untuk membentuk advanced glycosylated endproducts (AGEs). Adanya AGEs inilah yang dapat merusak dinding pembuluh darah bagian dalam, dan dapat menarik lemak yang jenuh atau kolesterol. Kolesterol yang menempel pada dinding pembuluh darah menyebabkan terjadinya reaksi inflamasi, sehingga leukosit dan trombosit serta sel mediator inflamasi lain menuju tempat inflamasi. Sel-sel tersebut menyatu menjadi suatu plak yang menjadikan dinding pembuluh darah keras, kaku dan akhirnya terjadi penyempitan sehingga menyebabkan perubahan tekanan darah (Setiyorini et al., 2018).

Baik hipertensi maupun diabetes melitus merupakan masalah yang perlu mendapat perhatian karena tingginya angka penderitanya, terlebih jika terjadi komplikasi keduanya. Oleh karena itu, penanganan yang tepat merupakan salah satu hal yang dapat diupayakan, salah satunya dengan terapi obat yang tepat guna mengurangi morbiditas, mortalitas dan biaya (Ernst \& Grizzle,

Seminar Nasional Asosiasi Perguruan Tinggi Farmasi Indonesia (APTFI) III-Tantangan Pandemik (covid-19) dalam pembelajaran dan penelitian kefarmasian 16-20 Agustus 2021 (Virtual Conference) 
2001). Oleh karena itu, penelitian ini bertujuan untuk mengetahui profil pengobatan dan potensi interaksi obat pada pasien diabetes mellitus komplikasi hipertensi di RSUD dr. H. Andi Abdurrahman Noor. Rumah sakit ini termasuk salah satu tempat rujukan pasien yang berdomisili di Kabupaten Tanah Bumbu, Kalimantan Selatan.

\section{Metode}

Penelitian ini bersifat deskriptif dan dilakukan secara retrospektif di Instalasi Farmasi Rawat Jalan RSUD dr. H. Andi Abdurrahman Noor. Pengambilan data dilakukan dengan menggunakan lembar resep Surat Eligibilitas Pasien (SEP) pasien Badan Penyelenggaraan Jaminan Sosial (BPJS) dengan diagnosis diabetes melitus komplikasi hipertensi selama periode Oktober-Desember 2020. Sebanyak 73 pasien yang memenuhi kriteria inklusi. Selanjutnya ditelaah obat-obatan yang digunakan pasien, serta potensi interaksi yang terjadi. Website drugs.com, Medscape dan Stockley digunakan sebagai rujukan untuk menganalisis potensi interaksi obat.

\section{Hasil dan pembahasan}

\subsection{Karakteristik pasien}

Karakteristik pasien dikategorikan berdasarkan jenis kelamin, usia, dan penyakit penyerta. Data karakteristik pasien dapat dilihat pada Tabel 1. Pada penelitian ini, ditemukan lebih banyak pasien laki-laki dari pada perempuan. Berdasarkan data hasil Riset Kesehatan Dasar 2018, perempuan mempunyai prevalensi lebih besar mengidap diabetes melitus (12,7\%) jika dibandingkan dengan laki-laki yaitu 10,6\% (Kemenkes, 2018). Perempuan lebih berisiko untuk mengidap penyakit diabetes melitus akibat sistem hormonal (menstruasi dan menopause) yang membuat lemak di tubuh lebih mudah terakumulasi (Irawan, 2010). Perbedaan hasil pada distribusi jenis kelamin dimungkinkan karena waktu studi yang pendek.

Tabel 1. Karakteristik pasien

\begin{tabular}{lll}
\hline Karakteristik pasien & Jumlah & Persentase (\%) \\
\hline Jenis kelamin & 40 & \\
Laki-laki & 43 & 54,79 \\
Perempuan & & 45,21 \\
\hline Usia & 1 & \\
$18-24$ & 1 & 1,37 \\
$25-34$ & 10 & 1,37 \\
$35-44$ & 17 & 13,70 \\
$45-54$ & 26 & 23,29 \\
$55-64$ & 18 & 35,62 \\
$65-74$ & & 24,65 \\
\hline
\end{tabular}

Seminar Nasional Asosiasi Perguruan Tinggi Farmasi Indonesia (APTFI) III-Tantangan Pandemik (covid-19) dalam pembelajaran dan penelitian kefarmasian 16-20 Agustus 2021 (Virtual Conference) 


\begin{tabular}{lcc}
\hline \multicolumn{3}{l}{ Penyakit penyerta lain (selain diabetes melitus komplikasi hipertensi) } \\
Tanpa penyakit penyerta & 46 & 63,01 \\
1 Penyakit Penyerta & 23 & 31,51 \\
2 Penyakit Penyerta & 4 & 5,48 \\
\hline
\end{tabular}

Usia terbanyak ada pada rentang 55-64 sebanyak 26 Kasus (35,62\%). Semakin tua usia seseorang maka akan semakin besar kejadian DM tipe 2. Hal ini disebabkan karena adanya penurunan semua sistem dalam tubuh seiring dengan pertambahan usia seseorang, termasuk sistem endokrin, yang biasanya terjadi resistensi insulin (Isnaini \& Ratnasari, 2018). Selain itu, angka harapan hidup Kabupaten Tanah Bumbu adalah 70,08 tahun sehingga banyak ditemui pasien yang berusia lanjut (BPS Kalsel, 2020).

\subsection{Penyakit penyerta}

Terdapat 12 penyakit penyerta komplikasi DM selain hipertensi. Data tersebut dapat dilihat pada tabel 2. Berdasarkan karakteristik penyakit penyerta pada penelitian ini terbanyak adalah coronary artery disease, dyspepsia syndrome, dan hiperkolesterolemia. Coronary artery disease (CAD) disebut juga sebagai jantung koroner. Dalam sistem pembuluh darah, arteri koroner bertugas membawa darah ke jantung. Jika terjadi penyempitan atau penyumbatan di area ini, maka seseorang dapat menderita penyakit arteri koroner (Hanson et al., 2013). Faktor risiko penyakit ini diantaranya yakni hipertensi dan DM (Rahmandityo, 2016) (Rahmandityo, 2016). Penelitian yang dilakukan oleh Tomizawa dkk (2015) menyebutkan bahwa DM lebih memperparah penyakit jantung koroner dibandingkan hipertensi.

Tabel 2. Penyakit penyerta

\begin{tabular}{lll}
\hline Penyakit penyerta & Jumlah & Persentase (\%) \\
\hline Coronary artery disease & 5 & 16,13 \\
Dyspepsia syndrome & 5 & 16,13 \\
Hiperkolesterolemia & 5 & 16,13 \\
Congestive heart failure & 3 & 9,67 \\
Arthritis & 3 & 9,67 \\
ISPA & 3 & 9,67 \\
Chronic kidney disease & 2 & 6,45 \\
GERD & 1 & 3,23 \\
Kardiomegali & 1 & 3,23 \\
Gout & 1 & 3,23 \\
Gastropati DM & 1 & 3,23 \\
Neuropati DM & 1 & 3,23 \\
\hline ISPA: infeksi saluran pernapasan atas; GERD: gastroesophageal reflux disease
\end{tabular}

ISPA: infeksi saluran pernapasan atas; GERD: gastroesophageal reflux disease

Dyspepsia syndrome merupakan rasa tidak nyaman pada perut bagian atas (epigastrium). Gejala yang biasanya muncul seperti nyeri dan rasa terbakar pada epigastrium, perut terasa penuh setelah makan, cepat kenyang, rasa kembung, mual, muntah, dan sendawa (Simadibrata et al., 
2014). Menurut penelitian Lestari dkk (2019) terdapat hubungan antara kadar glycosylated hemoglobin (HbA1c) dengan angka kejadian dyspepsia syndrome pada penderita DM tipe 2 sebesar $76,62 \%$.

Penyakit penyerta seperti hiperkolesterolemia dapat disebabkan kondisi DM. Tingginya kadar gula di dalam darah karena tidak dapat terserap semuanya oleh sel-sel tubuh dapat menyebabkan kadar LDL meningkat dan menurunkan kadar HDL (Lestari et al., 2019). Tingginya kadar LDL akan menyebabkan penumpukan kolesterol di pembuluh darah sehingga terjadi penyempitan serta dinding pembuluh darah menjadi kaku. Hal ini yang menyebabkan tekanan darah meningkat (Maryati, 2017).

\subsection{Profil pengobatan}

Profil pengobatan yang diterima pasien meliputi obat golongan antidiabetes dan antihipertensi. Selain mendapatkan terapi untuk pengobatan diabetes melitus dan hipertensi, pasien juga mendapatkan terapi untuk mengatasi keluhan atau penyakit penyerta yang dialami pasien. Penentuan golongan terapi yang diterima disesuaikan dengan penggolongan terapi pada Pusat Informasi Obat Nasional (BPOM, 2015a).

Tabel 3. Profil pengobatan antidiabetes

\begin{tabular}{|c|c|c|c|c|}
\hline Golongan & & Nama obat & Jumlah & $\begin{array}{l}\text { Persentase } \\
(\%)\end{array}$ \\
\hline Insulin (rapid-acting) & & Insulin aspart & 32 & 43,84 \\
\hline $\begin{array}{l}\text { Insulin } \\
\text { long-acting) }\end{array}$ & + & Insulin aspart + detemir & 29 & 39,72 \\
\hline Insulin (long-acting) + biguanid & & Detemir + metformin & 5 & 6,85 \\
\hline Biguanid + sulfonilurea & & Metformin+ glimepirid & 3 & 4,11 \\
\hline Sulfonilurea & & Glimepirid & 3 & 4,11 \\
\hline Biguanid & & Metformin & 1 & 1,37 \\
\hline Total & & & 73 & 100 \\
\hline
\end{tabular}

Pada penelitian ini hanya didapatkan pasien yang memiliki diagnosa DM tipe 2, sedangkan DM tipe 1 tidak ditemukan. Penggunaan insulin aspart tunggal merupakan penggunaan terbanyak sebagai terapi antidiabetes (Tabel 3). Pemberian insulin dari awal terdiagnosis dapat memberikan clinical outcome yang dapat dilihat dari perbaikan fungsi sel beta pankreas, pencegah kerusakan pembuluh darah, menghambat proses peradangan, menurunkan kejadian apoptosis, serta memperbaiki profil lipid (Sepmawati, 2016). Pada pasien DM tipe 2, insulin biasanya mulai diberikan ketika pasien mengalami kegagalan dalam penggunaan terapi oral, kontrol kadar glukosa yang buruk (HbA1c >7,5\%), kadar glukosa darah saat puasa $\geq 250 \mathrm{mg} / \mathrm{dl}$, riwayat penggunaan terapi oral lebih dari 5 tahun, dan/atau pasien DM lebih dari 10 tahun (Rismayanthi, 2010). 
Tabel 4. Profil pengobatan antihipertensi

\begin{tabular}{llll}
\hline Golongan & Nama obat & Jumlah & Persentase (\%) \\
\hline ARB + CCB & Kandesartan + amlodipin & 38 & 52,05 \\
ARB & Kandesartan & 17 & 23,29 \\
CCB & Amlodipin & 14 & 19,18 \\
ARB + CCB + Diuretik loop & Kandesatan + amlodipin + furosemid & 2 & 2,74 \\
ARB + Diuretik loop & Kandesartan + furosemid & 1 & 1,37 \\
ARB + CCB 1 + CCB 2 & Kandesartan + amlodipin + diltiazem & 1 & 1,37 \\
\hline
\end{tabular}

ARB: angiotensin receptor blocker; CCB: calcium channel blocker

Pada penelitian ini penggunaan terapi antihipertensi yang paling banyak digunakan adalah kombinasi ARB + CCB berupa kandesartan dan amlodipin (Tabel 4). Tujuan utama terapi hipertensi adalah untuk mencapai dan mempertahankan target tekanan darah sehingga kejadian mortalitas dan morbiditas yang berkaitan dengan kerusakan organ dapat ditekan. Kombinasi antara amlodipin dan kandesartan merupakan kombinasi obat yang tepat karena memiliki mekanisme kerja yang berbeda dalam menurunkan tekanan darah, sehingga bisa meminimalkan terjadinya toksisitas (Darnindro \& Muthalib, 2008). Dengan mengkombinasikan antara amlodipin dan kandesartan dapat mencegah terjadinya diabetes nefropati pada pasien DM komplikasi hipertensi (Kalra et al., 2010). Efek samping penggunaan golongan CCB tunggal seperti edema perifer dapat menurun secara signifikan apabila dikombinasikan dengan golongan ARB (Mallat et al., 2013).

\subsection{Potensi interaksi obat}

Potensi interaksi antara obat golongan antihipertensi, antidiabetes dan obat golongan lain yang diterima pasien dapat dilihat pada Tabel 5. Total pasien yang mengalami interaksi obat sebanyak 73 orang. Satu pasien bisa mengalami lebih dari satu potensi interaksi.

Tabel 5. Potensi interaksi obat

\begin{tabular}{|c|c|c|c|c|c|c|c|}
\hline \multicolumn{2}{|c|}{ Nama obat } & \multirow{2}{*}{$\begin{array}{c}\begin{array}{c}\text { Tingkat } \\
\text { keparahan* }\end{array} \\
\text { Moderate }\end{array}$} & \multirow{2}{*}{\begin{tabular}{l}
\multicolumn{1}{c}{$\begin{array}{c}\text { Tingkat } \\
\text { keparahan** }\end{array}$} \\
Monitor \\
closely
\end{tabular}} & \multirow[b]{2}{*}{$\begin{array}{l}5 \\
5\end{array}$} & \multirow{2}{*}{$\begin{array}{l}\begin{array}{l}\text { Persentase } \\
\text { (\%) }\end{array} \\
73,34\end{array}$} & \multirow{2}{*}{$\begin{array}{l}\text { Mekanisme } \\
\text { interaksi } \\
\text { Unknown }^{* *}\end{array}$} & \multirow{2}{*}{$\begin{array}{l}\text { Solusi } \\
\begin{array}{l}\text { Monitoring gula } \\
\text { darah secara } \\
\text { rutin }\end{array} \\
\end{array}$} \\
\hline Insulin & Kandesartan & & & & & & \\
\hline Metformin & Amlodipin & - & $\begin{array}{l}\text { Monitor } \\
\text { closely }\end{array}$ & 6 & 8,22 & $\begin{array}{l}\text { Pharmaco-dy } \\
\text { namic }^{* *}\end{array}$ & $\begin{array}{l}\text { Monitoring gula } \\
\text { darah secara } \\
\text { rutin }\end{array}$ \\
\hline Amlodipin & Diltiazem & Moderate & $\begin{array}{l}\text { Serious-use } \\
\text { alternative }\end{array}$ & 1 & 1,37 & $\begin{array}{l}\text { Pharmaco-kin } \\
\text { etics ** }\end{array}$ & $\begin{array}{l}\text { Memberikan jeda } \\
\text { waktu dalam } \\
\text { penggunaan atau } \\
\text { mengganti } \\
\text { kombinasi }\end{array}$ \\
\hline
\end{tabular}

*Berdasarkan Drugs.com

***Berdasarkan Medscape

Potensi interaksi yang paling tinggi terjadi pada interaksi antara insulin dengan kandesartan yaitu sebanyak 55 kasus dengan tingkat keparahan moderat (Drugs.com, 2021; Medscape, 2021). 
Interaksi dapat dikategorikan berdasarkan mekanisme interaksinya yaitu interaksi farmakokinetik dan interaksi farmakodinamik (Baxter, 2010; Drugs.com, 2021; Medscape, 2021).

Pada tabel diatas dapat dilihat bahwa interaksi terbanyak terjadi pada penggunaan kandesartan dengan insulin baik detemir maupun aspart akan meningkatkan sensitivitas insulin dengan mekanisme interaksi yang tidak diketahui. Jika insulin dan kandesartan digunakan secara bersamaan akan mengakibatkan hipoglikemia. Selain itu, penggunaan amlodipin dengan metformin dapat menurunkan efek kerja dari metformin melalui antagonis farmakodinamik. Maka, perlu dilakukan pemeriksaan gula darah secara rutin terutama pada pasien dengan usia lanjut dan atau gangguan ginjal guna menghindari terjadinya hipoglikemia, atau dengan melakukan penyesuaian dosis insulin jika diduga ada interaksi (Medscape, 2021). Pasien harus diberitahu tentang tanda dan gejala hipoglikemia, seperti jantung berdebar, tremor, lemah lunglai, berkeringat, mual, lapar, pusing, sakit kepala, dan mengantuk, serta cara pengatasannya (Drugs.com, 2021).

Pada penelitian ini terdapat kombinasi obat antara amlodipin dan diltiazem, dimana kedua obat tersebut sama-sama merupakan golongan calcium channel blocker. Obat golongan ini dimetabolisme oleh enzim sitokrom P450 (CYP3A4). Kadar obat ini dapat menyebabkan toksisitas jika enzim pemetabolisme dihambat. Diltiazem termasuk substrat dan inhibitor enzim CYP3A4, sehingga diltiazem dapat berinteraksi dengan obat lain yang juga dimetabolisme oleh enzim tersebut. Ketika amlodipin dikombinasikan dengan diltiazem maka diltiazem akan mempengaruhi metabolisme enzim CYP3A4 di hati/usus yang mengakibatkan peningkatan kadar amlodipin sebesar 50\% dan disertai peningkatan efek amlodipin (Baxter, 2010; Medscape, 2021).

\section{Kesimpulan}

Insulin aspart adalah antidiabetes yang paling banyak digunakan, sedangkan kandesartan yang dikombinasi dengan amlodipin merupakan antihipertensi yang paling banyak digunakan. Kedua jenis obat tersebut (insulin dan kandesartan) memiliki potensi interaksi obat.

\section{Daftar pustaka}

American Diabetes Association. (2020). Standards of Medical Care in Diabetes. Diabetes Care, 43(2), 514.

Badan Pusat Statistika Kalsel. (2020). Angka Harapan Hidup. Retrieved from https://data.kalselprov.go.id/?r=HarapanHidup/index

Baxter, K. (2010). Stockley's Drug Interactions (9 ed.). China: Pharmaceutical Press.

BPOM. (2015a). Pusat Informasi Obat Nasional. Retrieved from http://pionas.pom.go.id/monografi

Darnindro, N., \& Muthalib, A. (2008). Tatalaksana Hipertensi pada Pasien dengan Sindrom Nefrotik. Majalah Kedokteran Indonesia, 58(2), 57. 
Dinkes Kalsel. (2020). Jumlah Penderita Penyakit Diabetes Mellitus. Retrieved from https://data.kalselprov.go.id/?r=JmlDiabetesm/index

Drugs.com. (2021). Drug Interactions Checker. Retrieved from www.drugs.com/interaction/list/?

Ernst, F. R., \& Grizzle, A. J. (2001). Drug-Related Morbidity and Mortality: Updating the Cost-of-Illness Model Journal of the American Pharmaceutical Association, 41(2), 192-199.

Hanson, M. A., Fareed, M. T., Argenio, S. L., Agunwamba, A. O., \& Hanson, T. R. (2013). Coronary Artery Disease. Prim Care, 40(1), 1-16.

International Diabetes Federation. (2019). IDF Diabetes Atlas (9 ed.): International Diabetes Federation.

Irawan, D. (2010). Prevalensi dan Faktor Risiko Kejadian Diabetes Melitus Tipe 2 di Daerah Urban Indonesia (Analisa Data Sekunder Riskesdas 2007). (Skripsi). Universitas Indonesia, Jakarta.

Isnaini, N., \& Ratnasari, R. (2018). Faktor Risiko Mempengaruhi Kejadian Diabetes Melitus Tipe Dua. Jurnal Kebidanan dan Keperawatan Aisyiyah, 14(1), 62-67.

Kalra, S., Kalra, B., \& Agrawal, N. (2010). Combination Therapy in Hypertension: An Update. Diabetol Metab Syndr, 2(1), 44. doi:10.1186/1758-5996-2-44

Kemenkes. (2018). Hasil Utama Riset Kesehatan Dasar (Riskesdas 2018).

Lestari, D. P., Uwan, W. B., \& Ilmiawan, M. I. a. (2019). Hubungan antara Kadar Glycosylated Hemoglobin (HbA1c) dan Angka Kejadian Sindrom Dispepsia pada Penderita Diabetes Melitus Tipe 2. Kesehatan Khatulistiwa, 5(7), 21-23.

Mallat, S. G., Itani, H. S., \& Tanios, B. Y. (2013). Current Perspectives on Combination Therapy in The Management of Hypertension. Integr Blood Press Control, 6, 69-78. doi:10.2147/ibpc.S33985

Maryati, H. (2017). Hubungan Kadar Kolesterol dengan Tekanan Darah Penderita Hipertensi di Dusun Sidomulyo Desa Rejoagung Kecamatan Ploso Kabupaten Jombang. Jurnal Keperawatan, 8(2), 128-113.

Medscape. (2021). Drug Interaction Checker. Retrieved from https://reference.medscape.com/drug-interactionchecker

Rahmandityo, D. F. (2016). Hubungan Hipertensi dengan Keparahan Penyakit Jantung Koroner Berdasarkan Sullivan Vessel Score. (Bachelor). UIN Syarif Hidayatullah, Jakarta.

Rismayanthi, C. (2010). Terapi Insulin Sebagai Alternatif Pengobatan Bagi Penderita Diabetes. Medikora, 6(2). doi:http://dx.doi.org/10.21831/medikora.v0i2.4680

Rodbard, H. W., Blonde, L., Braithwaite, S. S., Brett, E. M., Cobin, R. H., Handelsman, Y., Hellman, R., Jellinger, P. S., Jovanovic, L. G., Levy, P., Mechanick, J. I., \& Zangeneh, F. (2007). American Association of Clinical Endocrinologists Medical Guidelines for Clinical Practice for The Management of Diabetes Mellitus. Endocr Pract, 13 Suppl 1, 1-68.

Sepmawati, N. D. (2016). Evaluasi Ketepatan Terapi pada Pasien Diabetes Melitus Tipe 2 di Instalasi Rawat Inap RS "A" Periode Januari - Juni 2015. (Skripsi). Universitas Muhammadiyah Surakarta, Surakarta.

Setiyorini, E., Wulandari, N. A., \& Efyuwinta, A. (2018). Hubungan Kadar Gula Darah dengan Tekanan Darah pada Lansia Penderita Diabetes Tipe 2. Jurnal Ners dan Kebidanan (Journal of Ners and Midwifery), 5(2), 163-171.

Simadibrata, M., D, Makmun, M., Abdullah, A. F., Syam, A., Fauzi, K., Renaldi, H., Maulahela, \& Utari, A. P. (2014). Konsensus Nasional Penatalaksanaan Dispepsia dan Infeksi Helicobacter Pylori. Retrieved from Jakarta:

Tomizawa, N., Nojo, T., Inoh, S., \& Nakamura, S. (2015). Difference of coronary Artery Disease Severity, Extent and Plaque Characteristics Between Patients with Hypertension, Diabetes Mellitus or Dyslipidemia. Int J Cardiovasc Imaging, 31(1), 205-212.

Seminar Nasional Asosiasi Perguruan Tinggi Farmasi Indonesia (APTFI) III-Tantangan Pandemik (covid-19) dalam pembelajaran dan penelitian kefarmasian 16-20 Agustus 2021 (Virtual Conference) 
